\title{
How well do the current state-of-the-art CMIP5 models characterise the climatology of the East Asian winter monsoon?
}

\author{
Ke Wei $\cdot$ Ting Xu $\cdot$ Zhencai Du $\cdot$ Hainan Gong • \\ Baohua Xie
}

Received: 7 May 2013/Accepted: 20 August 2013/Published online: 31 August 2013

(c) Springer-Verlag Berlin Heidelberg 2013

\begin{abstract}
Previous studies have revealed some common biases in coupled general circulation model's simulations of the East Asian (EA) winter monsoon (EAWM), including colder surface air temperature and more winter precipitation over the EA region. In this study, we examined 41 fully coupled atmosphere-ocean models from fifth phase of the Coupled Model Intercomparison Project (CMIP5), which will be widely used in the fifth assessment report of the Intergovernmental Panel on Climate Change (IPCC), and address whether the current state-of-the-art CMIP5 models can characterise the climatology of the East Asian winter monsoon. We also compared the results with the models from third phase of CMIP, which was extensively used in the fourth assessment report of the IPCC. The results show that the cold surface air temperature (SAT) bias is lessened and the precipitation amount decreased with the current CMIP5 models. Moreover, the CMIP5 models performbetter at predicting surface winds and high-level jet streams than the CMIP3 models. Moreover, CMIP5 models show more model consistency in most EAWM parameters, and the interannual variability of the SAT is closer to the observations. We also examined the change in the radiation energy budget in the CMIP5 models
\end{abstract}

K. Wei $(\bowtie) \cdot$ T. Xu $\cdot$ Z. Du $\cdot$ H. Gong

Center for Monsoon System Research, Institute of Atmospheric Physics, Chinese Academy of Sciences, P.O. Box 2718, ZhongGuan-Cun, Haidian District, Beijing 100190, People's Republic of China

e-mail: weike@mail.iap.ac.cn

B. Xie

Key Laboratory of Coastal Zone Environmental Processes and Ecological Remediation, Yantai Institute of Coastal Zone Research, Chinese Academy of Sciences, Yantai 264003, Shandong, People's Republic of China and compared with CMIP3 models. Although the improvements are significant, deficiencies still exist in the simulation of the EAWM, e.g., the stronger EA major trough and the stronger zonal sea level pressure gradient.

Keywords East Asian winter monsoon - CMIP5 CMIP3 - Climatology

\section{Introduction}

Climate models have become a primary tool in climate research as issues of climate change and the impacts of climate variability become increasingly important, receiving enormous attention and concern. They help improve prediction and adaption to climate change. The reliability of climate models, especially in depicting regional characteristics, is diminished because of the complexity of the feedbacks and processes involved in the different models. While the models agree reasonably well on many globally averaged and continental-scale aspects of climate change, there are still considerable uncertainties or errors with regional details of the projected changes. Thus, it's worthwhile to evaluate the spatial reproduction quality of the climate models. For East Asia (EA), associated with the thermal contrast between the largest ocean and largest continents, i.e., the Pacific Ocean and the Eurasian continent, the East Asian monsoon is one of the most energetic circulation components of the global climate system. There have been many studies that focus on model reproduction of the East Asian summer monsoon (e.g., Kang et al. 2002; Kim et al. 2008; Boo et al. 2011; Zhang and Chen 2011; Kusunoki and Arakawa 2012; Paul and Hsu 2012; Tian et al. 2012). Several studies on the projection of the East Asian winter monsoon (EAWM) are also available (e.g., Hu et al. 2000; Kimoto 2005; Hori and 
Ueda 2006; Jiang et al. 2010; Wei and Bao 2012). However, compared to its summer counterpart, much less research has been devoted to understanding the EAWM.

The East Asian winter monsoon has global influences. It exerts influences not only in East Asia, but also on convection and sea surface temperatures near the maritime continent (Chang et al. 1979; Bueh and Ji 1999), Australian summer monsoon (Zhang and Zhang 2010), climate in North America (Yang et al. 2002), ENSO evolution, intensity and periodicity (Lau and Peng 1987; Huang et al. 2004; $\mathrm{Li}$ et al. 2007), and the subsequent Asian summer monsoon (EASM) (e.g., Sun and Sun 1994; Chen et al. 2000; Yan et al. 2011). In its extreme state, it can bring excessive damage and large economic loss to the densely populated East Asian countries. For example, in February 2008 the unusual EAWM caused extremely low temperatures, blizzards, and freezing rain over a large region of southern China. The economic losses were estimated at $\sim \$ 25$ billion and 129 casualties occurred (Gu et al. 2008; Tao and Wei 2008; Zhou et al. 2009; Bao et al. 2010). Moreover, it was shown that the EAWM has been more active than normal starting from the mid-2000s (Chang et al. 2011; Wei et al. 2011). Therefore, it's very meaningful and even imperative to understand EAWM anomalies and to characterise its variations. Additionally, the EAWM is highly associated with various external and internal forcings, such as ENSO ( $\mathrm{Li} \mathrm{1990;} \mathrm{Zhang} \mathrm{et} \mathrm{al.}$ 1996; Chen et al. 2000; Wu et al. 2003), thermal effects of the Tibetan Plateau (Ye and Gao 1979; Wu and Zhang 1998), Eurasian snow cover (Watanabe and Nitta 1999; Wang et al. 2010), Arctic Oscillation (Gong et al. 2001; Wu and Wang 2002), North Atlantic Oscillation (Watanabe 2004), Planetary wave activities (Chen et al. 2005b). Therefore, the ability to reproduce the basic characteristics of EAWM can be used as an important benchmark to evaluate climate model's regional performance.

Previous studies on the reproduction of the EAWM have shown some common model biases. For example, Jiang et al. (2005) have used 7 coupled global general circulation models (CGCMs) to evaluate the performance of individual and multi-model ensemble mean climatology. They showed that cold simulation errors are generally present in each of the four seasons. The regional $\left(15^{\circ}-60^{\circ} \mathrm{N}\right.$ and $\left.70^{\circ}-140^{\circ} \mathrm{E}\right)$ average error of the winter surface air temperature was $-2.64{ }^{\circ} \mathrm{C}$. The cold bias is confirmed by other studies (Bueh 2003; Min et al. 2004; He and Wang 2012). In addition, Jiang et al. (2005) showed that winter sea level pressure is overestimated in East Asia and the simulated center of cold high pressure over Mongolia is displayed southward by approximately 4 degrees relative to reanalysis data. Hori and Ueda (2006) showed that the standard deviation for the $850-\mathrm{hPa}$ zonal wind is larger than the observed value. Furthermore, Min et al. (2004) found positive biases in winter precipitation over East Asia. In East
Asia region, the subtropical region has too much winter rainfall in the simulation of FGOALS-s2 [figure 14 of (Bao et al. 2013)]. The winter upper-level jet streams over East Asia simulated by the LASG/IAP coupled climate system model FGOALS-s2 was weaker than in the National Centers for Environment Prediction (NCEP)-Department of Energy (DOE) Atmospheric Model Inter-comparison Project II reanalysis data (NCEP2) (Song and Zhou 2013).

Modeling scientists are making great efforts to improve climate models. This includes the large number of coordinated experiments for the previous four IPCC (Intergovernmental Panel on Climate Change) assessment reports. In preparation for the future IPCC fifth assessment report (AR5), the worldwide modelling groups have updated and developed the coupled climate models to earth system models, which usually include atmosphere, ocean, ice, and land surface processes with dynamical vegetation. Furthermore, most models are using finer resolution and updated physical processes, including those for cloud parameterisation, and solar penetration schemes. Therefore, it's anticipated that the next generation of climate models will have increased performance with smaller error biases and improved consistency between models. Hence, it is of interest to examine the CGCMs' climatology performances under present day conditions in East Asia, and analyse their potential improvements compared to the models used in the fourth IPCC assessment report (AR4).

In this study, 41 CGCMs from the fifth phase of the Coupled Model Intercomparison Project (CMIP5), which will be used for evaluation in the AR5, are used to evaluate their ability to reproduce the EAWM. Meanwhile, 24 CGCMs from the third phase of CMIP (CMIP3), which were used for the AR4 evaluation, are utilised for comparison to examine the possible improvements in the simulations of EAWM climatology. The consideration of the CGCMs' simulation of EAWM climatology can assist in determining whether these climate models have the ability to predict climate on regional spatial scale and on decadal timescales, and provide reliable prediction products for the near future.

The layout of this paper is as follows. Section 2 of this paper provides the models and observation-based data used, followed in Sect. 3 by a presentation of the CMIP5 EAWM climatology. We analyzed the modelled EAWM interannual variability in Sect. 4, and the model seasonal cycle of the winter monsoon in Sect. 5. A brief discussion and summaries are given in the last section.

\section{Models and data}

\subsection{CGCMs output availability}

CMIP organized modelling groups from around the world and provided large multi-model dataset created by the 
state-of-the-art model simulation, which is freely available (Taylor et al. 2012). CMIP5 succeeds the previously successful third phase of CMIP (see Meehl et al. 2005), which for the first time released the climate model output almost immediately and freely upon completion of the runs to scientists outside the modelling groups. This unprecedented openness of the multi-model dataset provided the basis for the IPCC's AR4 assessment of climate variability and climate change. CMIP5 provides a framework for coordinated climate change experimentation and is expected to yield new insights regarding the climate system and the processes responsible for climate change and variability. More than 20 modelling groups performed CMIP5 simulations using more than 50 models, providing the best dataset to evaluate the CGCMs' ability to characterise regional phenomena, e.g., EAWM.

The 41 couple climate model outputs involved in this study are provided by the US Department of Energy's Program for Climate Model Diagnosis and Intercomparison (PCMDI, http://cmip-pcmdi.llnl.gov/). The names of the analysed models are listed together with the model resolution of the atmosphere and ocean components in Table 1. Table 1 is compiled using information that the participating modelling centres provided to the PCMDI (see http:// cmip-pcmdi.llnl.gov/ for additional model information). For comparison with the observation-based data, simulation results from 1961 to 1990 , the focus period in this analysis, is adopted from the historical run, which is forced by the atmospheric composition change of both anthropogenic and natural sources, and for the first time including time-evolving land cover change.

The 24 CGCM outputs, which were released by CMIP3 and used for the AR4 evaluation, are provided by the IPCC Data Distribution Center (ftp://ftp-esg.ucllnl.org) and the Hadley Centre for Climate Prediction and Research. The names and model resolution of the atmosphere and ocean components of the analysed CMIP3 models are listed in Table 2. The simulation results from 1961 to 1990 are adopted from the 20C3M run (twentieth Century Climate in Coupled Models), which is forced by the observed atmospheric composition changes, including sulphate aerosol concentration changes and the effects of greenhouse gases from both anthropogenic and natural sources. Therefore, the historical run of CMIP5 and 20C3M run of CMIP3 closely resemble observations. To be consistent with the reanalysis datasets, all of the simulation results were converted to a horizontal grid resolution of $2.5^{\circ} \times 2.5^{\circ}$

\subsection{Observation-based data}

The datasets used to evaluate the models included the reanalysis circulation fields, monthly mean temperature, geopotential height, and horizontal velocity from the European Centre for Medium-Range Weather Forecasts' (ECMWF) 45-year (1957-2002) ERA40 reanalysis dataset (Uppala et al. 2005). These data have a grid resolution of $2.5^{\circ} \times 2.5^{\circ}$ and extend from 1,000 to $1 \mathrm{hPa}$ with 23 vertical pressure levels. The ERA40 reanalysis surface air temperature (SAT), surface zonal and meridional wind, and sea-level pressure (SLP) were also examined. Additionally, monthly surface temperature data from 160 meteorological stations across China, collected and compiled by the China Meteorological Administration (CMA) from January 1951 to the present were used.

We also used precipitation reconstruction data from NOAA (National Oceanic and Atmospheric Administration), which is an analysis of constructed monthly precipitation gridded data over the globe for the period from 1948 to the present (http://www.esrl.noaa.gov/psd/data/gridded/ data.prec.html). The land portion of this global analysis is defined by optimum interpolation of gauge observations at over 17,000 stations collected from NOAA's National Climatic Data Center GHCN (Global Historical Climatology Network) Version 2 and the NOAA's Climate Prediction Center CAMS (Climate Anomaly Monitoring System) datasets. The oceanic precipitation analysis is produced by EOF reconstruction of historical gauge observations over island and land areas (Chen et al. 2002).

Our analyses focused on the boreal winter. Therefore, the wintertime mean was computed by averaging 3-month periods [December-February (DJF)] in each year. The climatological wintertime means were calculated by averaging each DJF over the period of model experiments.

\section{The model climatology of the EAWM}

\subsection{The main EAWM features}

The EAWM is highly associated with the stationary planetary-scale asymmetric topographic and diabatic heating forcings that arise from the distribution of land and oceans (Lau and Chang 1987; Chan and Li 2004). Therefore, it is characterised by a strong zonal (west-east) pressure gradient between the Siberian high and the Aleutian low, prevailing northerlies blowing over East Asia coastal regions, a southward extension of surface cold air and the Siberian high downstream of the Tibetan Plateau over eastern China, a deep long-wave trough in the middle levels and a strong jet stream at the higher levels. Accordingly, the model evaluation of the EAWM can be based on the states of near surface northerlies, surface air temperature (SAT), the 500-hPa trough and the 200-hPa jet stream. 
Table 1 Description of the CMIP5 (IPCC-AR5) coupled models used in this paper

\begin{tabular}{|c|c|c|c|}
\hline Model no. & CGCM model name & Institution and country & $\begin{array}{l}\text { Resolution }^{\mathrm{a}} \\
(\text { Lon } \times \text { Lat } \times \text { Lev }) \\
\text { AGCM/OGCM }\end{array}$ \\
\hline 1. & ACCESS1-0 & \multirow{2}{*}{$\begin{array}{l}\text { CSIRO (Commonwealth Scientific } \\
\text { and Industrial Research } \\
\text { Organisation, Australia), and BOM } \\
\text { (Bureau of Meteorology, Australia), } \\
\text { Australia }\end{array}$} & \multirow[t]{2}{*}{$192 \times 144 \mathrm{~L} 38 / 360 \times 300 \mathrm{~L} 50$} \\
\hline 2. & ACCESS1-3 & & \\
\hline 3. & bcc-csm1-1 & $\begin{array}{l}\text { Beijing Climate Center, China } \\
\text { Meteorological Administration, } \\
\text { China }\end{array}$ & $128 \times 64 \mathrm{~L} 26 / 360 \times 232 \mathrm{~L} 40$ \\
\hline 4. & BNU-ESM & $\begin{array}{l}\text { College of Global Change and Earth } \\
\text { System Science, Beijing Normal } \\
\text { University, China }\end{array}$ & $128 \times 64 \mathrm{~L} 26 / 360 \times 200 \mathrm{~L} 50$ \\
\hline 5. & *CanCM4 & \multirow{2}{*}{$\begin{array}{l}\text { Canadian Centre for Climate } \\
\text { Modelling and Analysis, Canada }\end{array}$} & $128 \times 64 \mathrm{~L} 35 / 256 \times 192 \mathrm{~L} 40$ \\
\hline 6. & CanESM2 & & $128 \times 64 \mathrm{~L} 35 / 256 \times 192 \mathrm{~L} 40$ \\
\hline 7. & *CCSM4 & \multirow{5}{*}{$\begin{array}{l}\text { National Center for Atmospheric } \\
\text { Research, USA }\end{array}$} & $192 \times 288 \mathrm{~L} 26 / 320 \times 384 \mathrm{~L} 60$ \\
\hline 8. & *CESM1-BGC & & $192 \times 288 \mathrm{~L} 26 / 320 \times 384 \mathrm{~L} 60$ \\
\hline 9. & *CESM1-CAM5 & & $192 \times 288 \mathrm{~L} 26 / 320 \times 384 \mathrm{~L} 60$ \\
\hline 10. & *CESM1-FASTCHEM & & $192 \times 288 \mathrm{~L} 26 / 320 \times 384 \mathrm{~L} 60$ \\
\hline 11. & *CESM1-WACCM & & $144 \times 96 \mathrm{~L} 23 / 192 \times 288 \mathrm{~L} 26 / 320 \times 384 \mathrm{~L} 60$ \\
\hline 12. & CMCC-CM & $\begin{array}{l}\text { Centro Euro-Mediterraneo per I } \\
\text { Cambiamenti Climatici, Italy }\end{array}$ & $480 \times 240 \mathrm{~L} 31 / 182 \times 149 \mathrm{~L} 31$ \\
\hline 13. & CNRM-CM5 & $\begin{array}{l}\text { Centre National de } \\
\text { RecherchesMeteorologiques/Centre } \\
\text { Europeen de Recherche et } \\
\text { Formation Avancees en } \\
\text { CalculScientifique, France }\end{array}$ & $255 \times 128 \mathrm{~L} 31 / 362 \times 292 \mathrm{~L} 42$ \\
\hline 14. & CSIRO-Mk-3-6-0 & $\begin{array}{l}\text { Commonwealth Scientific and } \\
\text { Industrial Research Organisation in } \\
\text { collaboration with the Queensland } \\
\text { Climate Change Centre of } \\
\text { Excellence, Australia }\end{array}$ & $192 \times 96 \mathrm{~L} 18 / 192 \times 189 \mathrm{~L} 31$ \\
\hline 15. & EC-EARTH & $\begin{array}{l}\text { European Earth System Model } \\
\text { Consortium, Europe }\end{array}$ & $320 \times 160 \mathrm{~L} 62 / 362 \times 292 \mathrm{~L} 42$ \\
\hline 16. & *FGOALS-g2 & $\begin{array}{l}\text { LASG, Institute of Atmospheric } \\
\text { Physics, Chinese Academy of } \\
\text { Sciences; and CESS, Tsinghua } \\
\text { University, China }\end{array}$ & $360 \times 180 \mathrm{~L} 26 / 360 \times 196 \mathrm{~L} 30$ \\
\hline 17. & FGOALS-s2 & $\begin{array}{l}\text { LASG, Institute of Atmospheric } \\
\text { Physics, Chinese Academy of } \\
\text { Sciences, China }\end{array}$ & $128 \times 108 \mathrm{~L} 26 / 360 \times 196 \mathrm{~L} 30$ \\
\hline 18. & *FIO-ESM & $\begin{array}{l}\text { The First Institution of Oceanography, } \\
\text { SOA, Qingdao, China }\end{array}$ & $128 \times 64 \mathrm{~L} 26 / 320 \times 384 \mathrm{~L} 40$ \\
\hline 19. & GFDL-CM3 & \multirow{3}{*}{$\begin{array}{l}\text { Geophysical Fluid Dynamics } \\
\text { Laboratory, USA }\end{array}$} & $144 \times 90 \mathrm{~L} 48 / 360 \times 200 \mathrm{~L} 50$ \\
\hline 20. & GFDL-ESM2G & & $144 \times 90 \mathrm{~L} 24 / 360 \times 210 \mathrm{~L} 50$ \\
\hline 21. & GFDL-ESM2M & & $144 \times 90 \mathrm{~L} 24 / 360 \times 200 \mathrm{~L} 50$ \\
\hline 22. & GISS-E2-H & \multirow{2}{*}{$\begin{array}{l}\text { NASA Goddard Institute for Space } \\
\text { Studies, USA }\end{array}$} & $144 \times 89 \mathrm{~L} 40 / 144 \times 90 \mathrm{~L} 33$ \\
\hline 23. & GISS-E2-R & & $144 \times 89$ L40/288 $\times 180$ L32 \\
\hline 24. & HadCM3 & $\begin{array}{l}\text { Met Office Hadley Centre, United } \\
\text { Kingdom }\end{array}$ & $96 \times 73 \mathrm{~L} 19 / 288 \times 144 \mathrm{~L} 20$ \\
\hline 25. & HadGEM2-AO & $\begin{array}{l}\text { National Institute of Meteorological } \\
\text { Research/Korea Meteorological } \\
\text { Administration, Korea }\end{array}$ & $192 \times 144 \mathrm{~L} 38 / 360 \times 216 \mathrm{~L} 40$ \\
\hline 26. & HadGEM2-CC & \multirow{2}{*}{$\begin{array}{l}\text { Met Office Hadley Centre, United } \\
\text { Kingdom }\end{array}$} & $192 \times 144 \mathrm{~L} 60 / 360 \times 216 \mathrm{~L} 40$ \\
\hline 27. & HadGEM2-ES & & $192 \times 144 \mathrm{~L} 38 / 360 \times 216 \mathrm{~L} 40$ \\
\hline
\end{tabular}


Table 1 continued

\begin{tabular}{|c|c|c|c|}
\hline Model no. & CGCM model name & Institution and country & $\begin{array}{l}\text { Resolution }(\text { Lon } \times \text { Lat } \times \text { Lev }) \\
\text { AGCM/OGCM }\end{array}$ \\
\hline 28. & inmcm 4 & $\begin{array}{l}\text { Institute for Numerical Mathematics, } \\
\text { Russia }\end{array}$ & $180 \times 120 \mathrm{~L} 21 / 360 \times 340 \mathrm{~L} 40$ \\
\hline 29. & IPSL-CM5A-LR & Institut Pierre-Simon Laplace, France & $96 \times 96 \mathrm{~L} 39 / 182 \times 149 \mathrm{~L} 31$ \\
\hline 30. & IPSL-CM5A-MR & & $144 \times 143 \mathrm{~L} 39 / 182 \times 149 \mathrm{~L} 31$ \\
\hline 31. & IPSL-CM5B-LR & & $96 \times 96 \mathrm{~L} 39 / 182 \times 149 \mathrm{~L} 31$ \\
\hline 32. & MIROC4 h & Atmosphere and Ocean Research & $640 \times 320 \mathrm{~L} 56 / 1280 \times 912 \mathrm{~L} 48$ \\
\hline 33. & MIROC5 & $\begin{array}{l}\text { Institute (The University of Tokyo), } \\
\text { National Institute for Environmental } \\
\text { Studies, and Japan Agency for } \\
\text { Marine-Earth Science and } \\
\text { Technology, Japan }\end{array}$ & $256 \times 128 \mathrm{~L} 40 / 256 \times 224 \mathrm{~L} 50$ \\
\hline 34. & MIROC-ESM & Japan Agency for Marine-Earth & $128 \times 64 \mathrm{~L} 80 / 256 \times 192 \mathrm{~L} 44$ \\
\hline 35. & MIROC-ESM-CHEM & $\begin{array}{l}\text { Science and Technology, } \\
\text { Atmosphere and Ocean Research } \\
\text { Institute (The University of Tokyo), } \\
\text { and National Institute for } \\
\text { Environmental Studies, Japan }\end{array}$ & $128 \times 64 \mathrm{~L} 80 / 256 \times 192 \mathrm{~L} 44$ \\
\hline 36. & MPI-ESM-LR & Max Planck Institute for Meteorology & $192 \times 96 \mathrm{~L} 47 / 256 \times 220 \mathrm{~L} 40$ \\
\hline 37. & MPI-ESM-MR & (MPI-M), Germany & $192 \times 96 \mathrm{~L} 47 / 802 \times 404 \mathrm{~L} 40$ \\
\hline 38. & MPI-ESM-P & & $192 \times 96 \mathrm{~L} 47 / 256 \times 220 \mathrm{~L} 40$ \\
\hline 39. & MRI-CGCM3 & $\begin{array}{l}\text { Meteorological Research Institute, } \\
\text { Japan }\end{array}$ & $320 \times 160 \mathrm{~L} 48 / 360 \times 368 \mathrm{~L} 51$ \\
\hline 40. & NorESM1-M & Norwegian Climate Centre, Norway & $144 \times 96 \mathrm{~L} 26 / 320 \times 384 \mathrm{~L} 70$ \\
\hline 41. & NorESM1-ME & & $144 \times 96 \mathrm{~L} 26 / 320 \times 384 \mathrm{~L} 70$ \\
\hline
\end{tabular}

The model information was attained from http://esgf.org/wiki/Cmip5Status and http://pcmdi-cmip.llnl.gov/cmip5/availability.html

* The surface zonal and meridional wind data (uas and vas, respectively) are not available in these models

${ }^{a}$ Horizontal resolution is expressed as number of zonal and meridional grid points. Vertical resolution (L) is the number of vertical levels

As shown in Fig. 1, the comparison of the CMIP5 historical run, CMIP3 20C3M run, ERA40 reanalysis and station observational data is made for the mean state of winter (DJF) SAT (represented by 0 and $10{ }^{\circ} \mathrm{C}$ isotherms, Fig. 1a), surface wind speed (represented by 5 and $8 \mathrm{~m} / \mathrm{s}$ isotachs, Fig. 1b), 200-hPa jet streak (represented by 60 and $70 \mathrm{~m} / \mathrm{s}$ isotach, Fig. 1c), and the $500-\mathrm{hPa}$ trough (represented by the trough axis, Fig. 1d). The lines are for multi-model ensemble (MME). The solid contours are $10{ }^{\circ} \mathrm{C}$ isotherms in Fig. $1 \mathrm{a}, 8 \mathrm{~m} / \mathrm{s}$ isotachs in Fig. $1 \mathrm{~b}$ and $70 \mathrm{~m} / \mathrm{s}$ isotachs in Fig. 1c, and the dashed contours are $0{ }^{\circ} \mathrm{C}$ isotherms in Fig. $1 \mathrm{a}, 5 \mathrm{~m} / \mathrm{s}$ isotachs in Fig. $1 \mathrm{~b}$ and $60 \mathrm{~m} / \mathrm{s}$ isotachs in Fig. 1c, respectively. Red contours are for the CMIP5 model simulations and green contours are for CMIP3 models. Compared with station observational and reanalysis data, the EAWM is well simulated by the current models. The magnitude of the surface winds and 200-hPa jet stream are very close to the reanalysis for both CMIP5 and CMIP3 simulations. The position of the 500-hPa trough axis and the SAT isotherms are reasonably well positioned in the models. Further examination of the details also shows improvement in the CMIP5 models in characterising the EAWM features, adding confidence to the modelling studies of the EAWM. Compared with the previous CMIP3 models, the two SAT isotherms for the CMIP5 models are more northward and closer to both the ERA40 reanalysis (black lines) and station observations (purple lines) in Fig. 1a. More importantly, the isotherms of the CMIP5 models are closer to the MME, while isotherms of the CMIP3 models have large spatial distributions (figure not shown). This indicates that improvements have been made both in the model average and model consistence in the CMIP5 models, which will help to define the appropriate southern boundary of the snowfield in EA. It is worth noting that very small SAT isotherm changes can be observed over North America between CMIP5 and CMIP3 simulations, except over western North America where distinct improvements were found (figure not shown).

Similar results are presented for the surface wind speed simulation (Fig. 1b). The strongest surface winds are usually observed along the coastal region of East Asia and over the South China Sea (SCS). Both CMIP5 and CMIP3 simulations have smaller wind speed over the SCS and East 
Table 2 Description of the CMIP3 (IPCC-AR4) coupled models used in this paper (Randall et al. 2007)

\begin{tabular}{|c|c|c|c|}
\hline Model no. & CGCM model name & Institution and country & $\begin{array}{l}\text { Atmospheric/Oceanic model } \\
\text { resolution }{ }^{\mathrm{a}} \text { (longitude by } \\
\text { latitude) }\end{array}$ \\
\hline 1. & BCCR_BCM2.0 & $\begin{array}{l}\text { Bjerknes Centre for Climate Research, } \\
\text { Norway }\end{array}$ & $\mathrm{T} 63 \mathrm{~L} 31 /\left(0.5^{\circ}-1.5^{\circ} \times 1.5^{\circ}\right) \mathrm{L} 35$ \\
\hline 2. & CGCM3.1(T47) & \multirow{2}{*}{$\begin{array}{l}\text { Canadian Centre for Climate Modelling } \\
\text { and Analysis, Canada }\end{array}$} & $\mathrm{T} 47 \mathrm{~L} 31 /\left(1.9^{\circ} \times 1.9^{\circ}\right) \mathrm{L} 29$ \\
\hline 3. & CGCM3.1(T63) & & $\mathrm{T} 63 \mathrm{~L} 31 /\left(0.9^{\circ} \times 1.4^{\circ}\right) \mathrm{L} 29$ \\
\hline 4. & CNRM_CM3 & $\begin{array}{l}\text { Météo-France/Centre National de } \\
\text { Recherches Météorologiques, France }\end{array}$ & $\mathrm{T} 63 \mathrm{~L} 45 /\left(0.5^{\circ}-2.0^{\circ} \times 2.0^{\circ}\right) \mathrm{L} 31$ \\
\hline 5. & CSIRO_MK3.0 & $\begin{array}{l}\text { Commonwealth Scientific and Industrial } \\
\text { Research Organisation (CSIRO) } \\
\text { Atmospheric Research, Australia }\end{array}$ & $\mathrm{T} 63 \mathrm{~L} 18 /\left(0.8^{\circ} \times 1.9^{\circ}\right) \mathrm{L} 31$ \\
\hline 6. & csiro_mk3_5 & $\begin{array}{l}\text { CSIRO Atmospheric Research, } \\
\text { Melbourne, Australia (CSIRO), } \\
\text { Australia }\end{array}$ & $\mathrm{T} 63 \mathrm{~L} 18 /(1.875 \times 0.925) \mathrm{L} 31$ \\
\hline 7. & GFDL_CM2.0 & $\begin{array}{l}\text { US Department of Commerce/National } \\
\text { Oceanic and Atmospheric }\end{array}$ & $\begin{array}{l}\left(2.0^{\circ} \times 2.5^{\circ}\right) \mathrm{L} 24 /\left(0.3^{\circ}-\right. \\
\left.1.0^{\circ} \times 1.0^{\circ}\right)\end{array}$ \\
\hline 8. & GFDL_CM2.1 & $\begin{array}{l}\text { Administration (NOAA)/Geophysical } \\
\text { Fluid Dynamics Laboratory } \\
\text { (GFDL),USA }\end{array}$ & $\begin{array}{l}\left(2.0^{\circ} \times 2.5^{\circ}\right) \mathrm{L} 24 /\left(0.3^{\circ}-\right. \\
\left.1.0^{\circ} \times 1.0^{\circ}\right)\end{array}$ \\
\hline 9. & GISS_AOM & \multirow{3}{*}{$\begin{array}{l}\text { National Aeronautics and Space } \\
\text { Administration(NASA)/Goddard } \\
\text { Institute for Space Studies(GISS), } \\
\text { USA }\end{array}$} & $\begin{array}{r}\left(3.0^{\circ} \times 4.0^{\circ}\right) \mathrm{L} 12 / \\
\left(3.0^{\circ} \times 4.0^{\circ}\right) \mathrm{L} 16\end{array}$ \\
\hline 10. & GISS_MODEL_EH & & $\begin{array}{r}\left(4.0^{\circ} \times 5.0^{\circ}\right) \mathrm{L} 20 / \\
\left(2.0^{\circ} \times 2.0^{\circ}\right) \mathrm{L} 16\end{array}$ \\
\hline 11. & GISS_MODEl_ER & & $\begin{array}{l}\left(4.0^{\circ} \times 5.0^{\circ}\right) \mathrm{L} 20 / \\
\left(4.0^{\circ} \times 5.0^{\circ}\right) \mathrm{L} 13\end{array}$ \\
\hline 12. & IAP_FGOALS1.0_G & LASG/IAP, China & $\mathrm{T} 42 \mathrm{~L} 26 /\left(1.0^{\circ} \times 1.0^{\circ}\right) \mathrm{L} 16$ \\
\hline 13. & *ingv_echam4 & $\begin{array}{l}\text { INGV (National Institute of Geophysics } \\
\text { and Volcanology, Bologna, Italy) }\end{array}$ & $\mathrm{T} 106 \mathrm{~L} 19 /\left(1.0^{\circ} \times 1.0^{\circ}\right) \mathrm{L} 33$ \\
\hline 14. & INMCM3.0 & $\begin{array}{l}\text { Institute of Numerical Mathematics, } \\
\text { Russia }\end{array}$ & $\begin{array}{l}\left(4.0^{\circ} \times 5.0^{\circ}\right) \mathrm{L} 21 / \\
\left(2.0^{\circ} \times 2.5^{\circ}\right) \mathrm{L} 33\end{array}$ \\
\hline 15. & IPSL_CM4 & $\begin{array}{l}\text { Institute Pierre Simon Laplace (IPSL), } \\
\text { France }\end{array}$ & $\begin{array}{r}\left(2.5^{\circ} \times 3.75^{\circ}\right) \mathrm{L} 19 / \\
\left(2.0^{\circ} \times 2.0^{\circ}\right) \mathrm{L} 31\end{array}$ \\
\hline 16. & MIROC3.2_HIRES & \multirow{2}{*}{$\begin{array}{l}\text { CCSR of Tokyo University, Frontier of } \\
\text { JAMSTEC, Japan }\end{array}$} & $\mathrm{T} 106 \mathrm{~L} 56 /\left(0.2^{\circ} \times 0.3^{\circ}\right) \mathrm{L} 47$ \\
\hline 17. & MIROC3.2_MEDRES & & $\mathrm{T} 42 \mathrm{~L} 20 /\left(0.5^{\circ}-1.4^{\circ} \times 1.4^{\circ}\right) \mathrm{L} 43$ \\
\hline 18. & MIUB_ECHO_G & $\begin{array}{l}\text { Meteorological Institute of the University } \\
\text { of Bonn, Meteorological Research } \\
\text { Institute of the Korea Meteorological } \\
\text { Administration (KMA), and Model and } \\
\text { Data Group, Germany/Korea }\end{array}$ & $\mathrm{T} 30 \mathrm{~L} 19 /\left(0.5^{\circ}-2.8^{\circ} \times 2.8^{\circ}\right) \mathrm{L} 20$ \\
\hline 19. & MPI_ECHAM5 & $\begin{array}{l}\text { Max Planck Institute for Meteorology } \\
\text { (MPI), Germany }\end{array}$ & $\mathrm{T} 63 \mathrm{~L} 31 /\left(1.5^{\circ} \times 1.5^{\circ}\right) \mathrm{L} 40$ \\
\hline 20. & MRI_CGCM2.3.2 & $\begin{array}{l}\text { Meteorological Research Institute (MRI), } \\
\text { Japan }\end{array}$ & $\mathrm{T} 42 \mathrm{~L} 30 /\left(0.5^{\circ}-2.0^{\circ} \times 2.5^{\circ}\right) \mathrm{L} 23$ \\
\hline 21. & *NCAR_CCSM3.0 & \multirow{2}{*}{$\begin{array}{l}\text { National Center for Atmospheric } \\
\text { Research (NCAR), USA }\end{array}$} & $\mathrm{T} 85 \mathrm{~L} 26 /\left(0.3^{\circ}-1.0^{\circ} \times 1.0^{\circ}\right) \mathrm{L} 40$ \\
\hline 22. & *NCAR_PCM1 & & $\mathrm{T} 42 \mathrm{~L} 26 /\left(0.5^{\circ}-0.7^{\circ} \times 1.1^{\circ}\right) \mathrm{L} 40$ \\
\hline 23. & UKMO_HADCM3 & \multirow[t]{2}{*}{$\begin{array}{l}\text { Hadley Center for Climate Prediction and } \\
\text { Research/Met Office, United Kingdom }\end{array}$} & $\begin{array}{l}\left(2.5^{\circ} \times 3.75^{\circ}\right) \mathrm{L} 19 / \\
\left(1.25^{\circ} \times 1.25^{\circ}\right) \mathrm{L} 20\end{array}$ \\
\hline 24. & UKMO_HADGEM1 & & $\begin{array}{l}\left(\sim 1.3^{\circ} \times 1.9^{\circ}\right) \mathrm{L} 38 /\left(0.3^{\circ}-\right. \\
\left.1.0^{\circ} \times 1.0^{\circ}\right) \mathrm{L} 40\end{array}$ \\
\hline
\end{tabular}

* The surface zonal and meridional wind data (uas and vas, respectively) are not available in these models

${ }^{a}$ Horizontal resolution is expressed either as degrees latitude by longitude or as a triangular (T) spectral truncation. Vertical resolution (L) is the number of vertical levels 
Fig. 1 A comparison of the CMIP5 historical run (red), CMIP3 20C3M run (green), ERA40 reanalysis (black) and station observational data (purple) for the EAWM fields: a the mean position of the surface $0{ }^{\circ} \mathrm{C}($ dash $)$ and $10{ }^{\circ} \mathrm{C}$ (solid) isotherms; b surface wind speed represented by $5 \mathrm{~m} /$ $\mathrm{s}$ (dash) and $8 \mathrm{~m} / \mathrm{s}$ (solid) isotachs; c 200-hPa jet streak represented by $60 \mathrm{~m} / \mathrm{s}$ (dash) and $70 \mathrm{~m} / \mathrm{s}$ (solid) isotachs; and d 500-hPa trough lines. The thick lines are for multi-model ensembles (MME) (a) $\operatorname{SAT} 0^{\circ} \mathrm{C} \& 10^{\circ} \mathrm{C}$

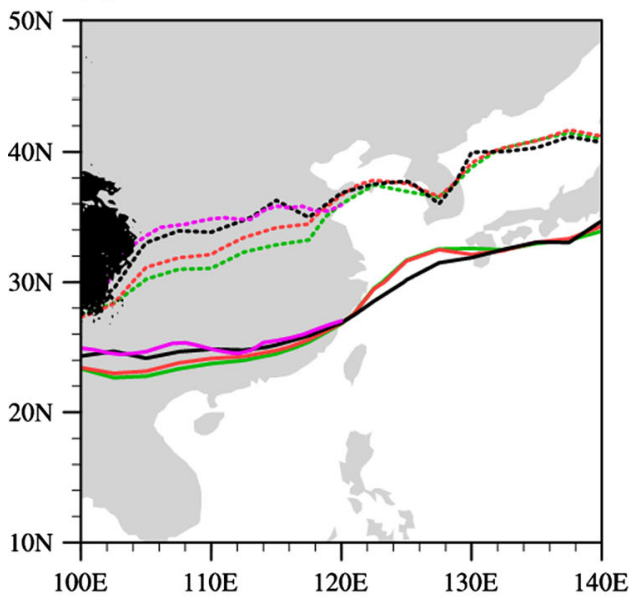

(c) Jet streak $200 \mathrm{hPa}$

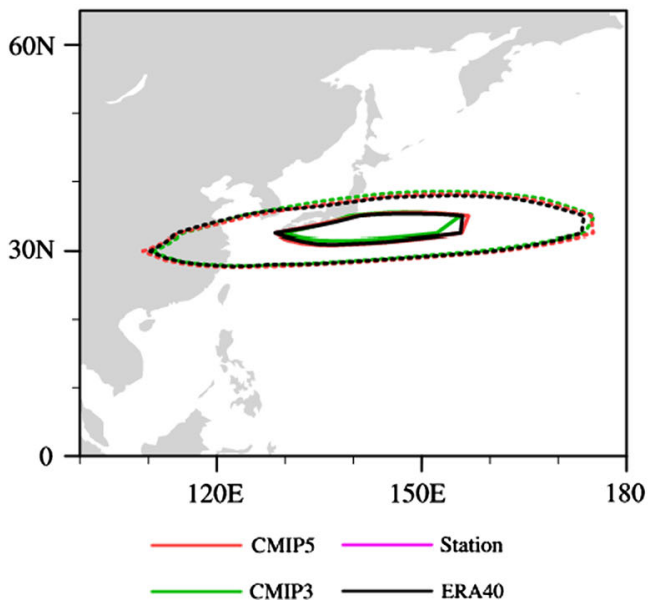

(b) VSP $5 \mathrm{~ms}^{-1} \& 8 \mathrm{~ms}^{-1}$

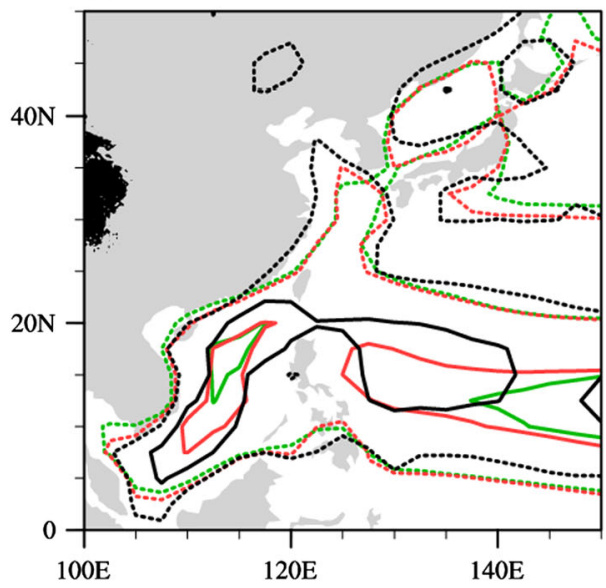

(d) trough $500 \mathrm{hPa}$

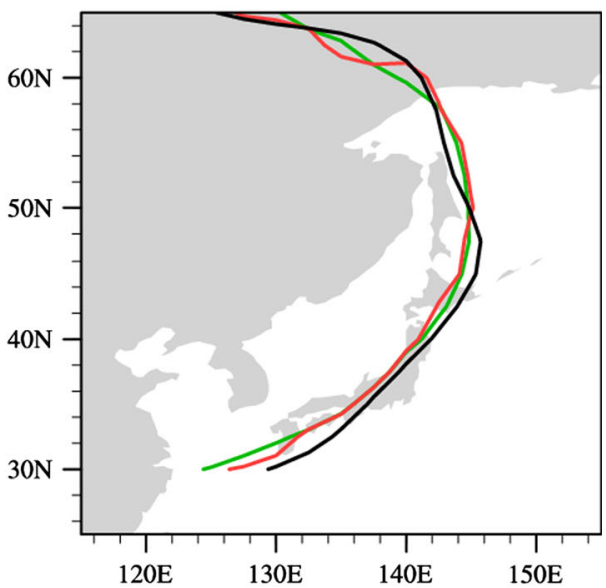

China Sea (ECS). While the surface wind speeds over the Indo-China Peninsula and coastal region of South China in the CMIP3 models are larger than observations. The improvements are significant in the CMIP5 simulations; the region enclosed by strong wind speed isotachs expands and is very close to the ERA40 reanalysis over the SCS. The wind speeds also increase and the wind speed isotachs of $5 \mathrm{~m} / \mathrm{s}$ extend westward over the ocean to the southeast of Japan, much closer to the ERA40 reanalysis in the CMIP5 than the CMIP3. The CMIP5 wind speed decreases over the Indo-China Peninsula and coastal region of South China, consequently, terminating the overestimate of surface wind speed in these regions.

The 200-hPa jet streak MME isotachs of 70 and $60 \mathrm{~m} / \mathrm{s}$ in the two model groups are very close to the ERA40 reanalysis. As previous studies (Chen et al. 2005a) have shown, the East Asian jet stream (EAJS) plays an important role in connecting the climate signals over Asia and North America, and is associated with the propagation of stationary wave activity. The reasonable and stable simulation of the EAJS can help to guarantee the general model performance in regard to the EAWM. A careful examination shows zonal wind overestimation and underestimation to the north and south of the jet streak in CMIP3, respectively. While the wind speed decreases to the north and increases to the south of the jet streak, leading the isotachs much closer to the ERA40 reanalysis in the CMIP5 models.

The exact location of the 500-hPa East Asian trough (EAT) axis is not well positioned in both the CMIP3 and CMIP5 models. While the axis tilt of the MME EAT southward of $45^{\circ} \mathrm{N}$ is smaller in the CMIP5 than in CMIP3 models, which is closer to the EAR40 climatology, indicating an improvement in the CMIP5 MME compared with the CMIP3 MME. It is believed that the tilt of the $500-\mathrm{hPa}$ East Asian trough (EAT) axis can have a significant modulation effect on regional climate anomalies. When the EAT tilt is small, the EAWM prefers to take the southern pathway and less cold air moves to the central North Pacific. Contrarily, the EAWM tends to take the eastern pathway and bring cold air to the North Pacific when the 
(a) Obs (NOAA) $\mathrm{mm} / \mathrm{day}$

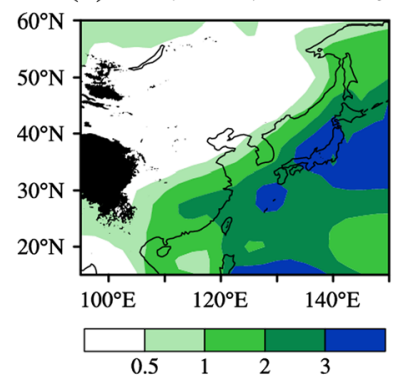

(c) MME (CMIP5)

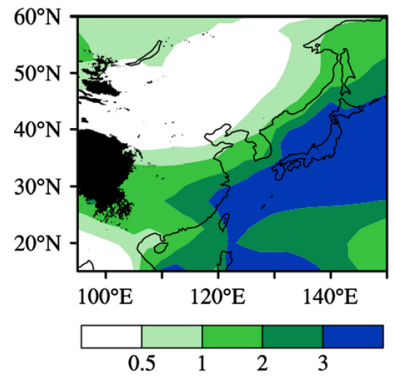

(e) MME (CMIP5-CMIP3),Conv.

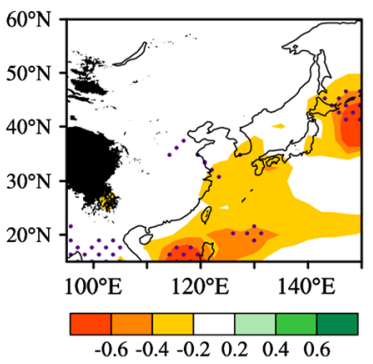

(b) MME (CMIP3)

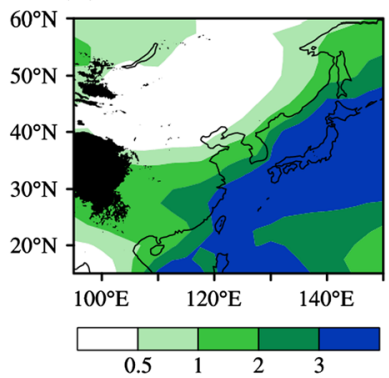

(d) MME (CMIP5-CMIP3)

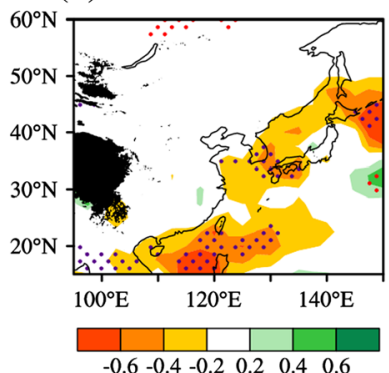

(f) MME (CMIP5-CMIP3),stra

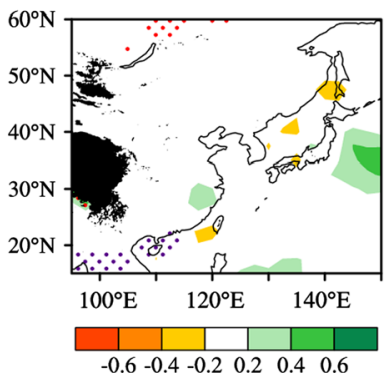

Fig. 2 The total precipitation rate from a NOAA's Precipitation Reconstruction data (30-year climatology from 1961 to 1990), b CMIP5-MME, c CMIP3-MME, d the differences between CMIP5-MME and CMIP3-MME, e the differences of convective precipitation between CMIP5-MME and CMIP3-MME, and $\mathbf{f}$ the differences in large-scale precipitation between CMIP5-MME and CMIP3-MME. The units are $\mathrm{mm} /$ day in all panels

EAT axis is more tilted (Wang et al. 2009). Therefore, the decrease of the EAT axis tilting in the CMIP5 simulation is closer to the observations and most likely associated with more synoptic cold air activities in East Asia than in the CMIP3 models.

\subsection{Precipitation}

Figure 2 compares the CMIP5 and CMIP3 precipitation climatology with observations for the winter season in the present-day climate simulations. The precipitation observed in the EAWM season is distributed mainly along the southeast coastal region, decreasing toward the northwest and north (Fig. 2a). The largest precipitation band

stretches from southeast China to Japan, with its eastern margin extending into the North Pacific storm track. Compared with its summer counterpart, a strong rain band stagnated over the Yangtze River valley, the EAWM has less precipitation and the rain band is more southward. The main features of the rain band and its northwestward decreasing pattern are well simulated by both the CMIP5 and CMIP3 MME. However, the two model groups generally overestimate the winter precipitation over the East China Sea, South Korea, Japan and eastern China coastline (Fig. 2b, c). A comparison between CMIP5 and CMIP3 (Fig. 2d) indicates that the CMIP5 models shows large improvements in the simulation of rainfall over the East Asia oceanic region (South China Sea, East China Sea, Sea of Japan, South Korea and southern Japan), indicating a partial compensation to the overestimation in the CMIP5 models. Further analysis reveals that this compensation is mainly due to the decrease in convective precipitation in the CMIP5 models (Fig. 2e). However, the stratiform rainfall (Fig. 2f) exhibits hardly any difference over these regions. As stratiform rainfall dominates over East Asia, with a percentage of approximately $50-85 \%$ in winter $(\mathrm{Du}$ et al. 2011), the overestimation of precipitation in the CMIP3 and CMIP5 models is most likely due to the overestimation of convective clouds in East Asia. The overall improvement of the CMIP5 models in simulating of precipitation indicates an improvement in the representation of the convective clouds and associated processes in East Asia. However, more model optimisation is still needed considering the excessive precipitation in the CMIP5 MME.

\subsection{The EAWM strength}

To assess the performance of the CMIP5 models at characterising the EAWM, we examined several key parameters that are commonly used to measure the strength or state of the EAWM (Fig. 3). These parameters include the following:

1. $I_{\mathrm{SATEC}}$, the SAT averaged for East Asia $\left(20^{\circ}-60^{\circ} \mathrm{N}\right.$, $\left.100^{\circ}-140^{\circ} \mathrm{E}\right)$

2. $I_{\text {SLPEC}}$, the SLP averaged over eastern China $\left(25^{\circ}\right.$ $40^{\circ} \mathrm{N}, 110^{\circ}-120^{\circ} \mathrm{E}$ ) (Wei and Bao 2012).

3. I ISLPdiff, the east-west pressure contrast, represented by the SLP difference between $110^{\circ} \mathrm{E}$ and $160^{\circ} \mathrm{E}$ and averaged from $10^{\circ} \mathrm{N}$ to $60^{\circ} \mathrm{N}$ (Guo 1994).

4. $I_{\mathrm{v}}$, the low-level northerlies index along the EA coastal region as in Chen and Sun (1999), from the northerly average at $1,000 \mathrm{hPa}$ for the domain defined by $15^{\circ}$ $30^{\circ} \mathrm{N}$ and $115^{\circ}-130^{\circ} \mathrm{E}$.

5. $I_{\text {trough }}$, the $500-\mathrm{hPa}$ trough index as in Cui and Sun (1999) using the $500 \mathrm{hPa}$ geopotential height averaged for the region defined by $35^{\circ}-40^{\circ} \mathrm{N}$ and $110^{\circ}-130^{\circ} \mathrm{E}$. 

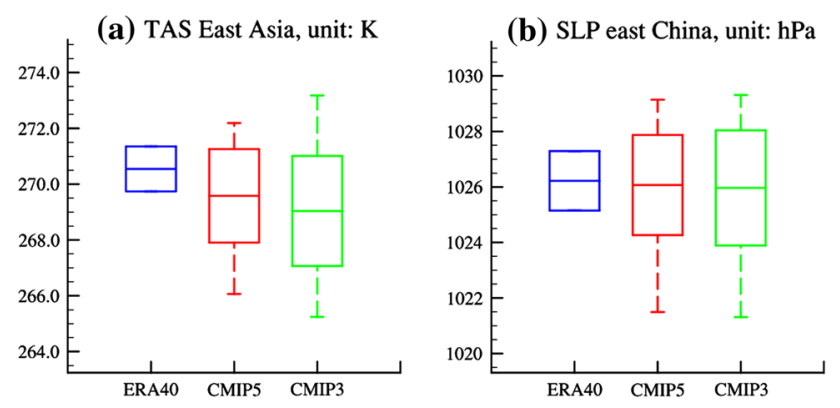

(c) SLP difference (110-160), unit: $\mathrm{hPa}$

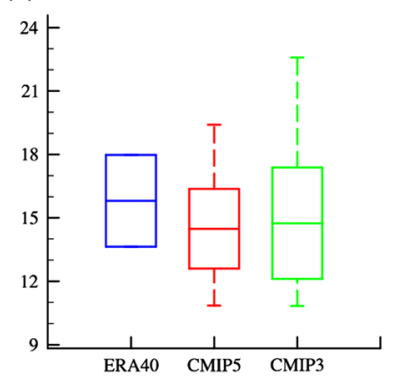

(e) trough strength $500 \mathrm{hPa}$, unit: gpm
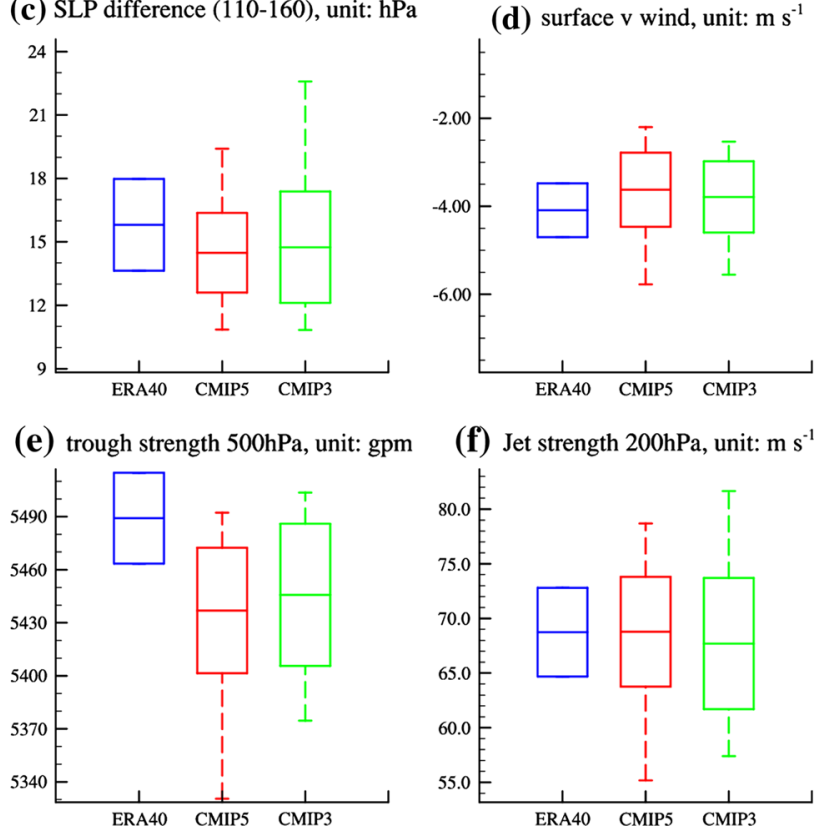

(f) Jet strength $200 \mathrm{hPa}$, unit: $\mathrm{m} \mathrm{s}^{-1}$

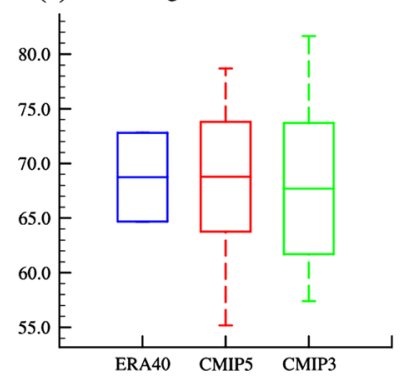

Fig. 3 Comparison of the EAWM climate parameters for a ISATEC, b ISLPEC, c ISLPdiff, $\mathbf{d}$ Iv, e Itrough, and $\mathbf{f}$ Ijet. The left blue boxes are for EAR-40 data with middle value for climatology and upper and lower values for one standard deviation. The middle red boxes are for the CMIP5 climatology with middle values for MME, upper and lower values for intra-model standard deviation, and upper and lower bars for maximum and minimum values. The right green boxes are for the CMIP3 climatology with middle values for MME, upper and lower value for intra-model standard deviation, and upper and lower bars for maximum and minimum value

6. $I_{\text {jet }}$, the 200-hPa East Asian jet strength index as in Yang et al. (2002) determined by the 200-hPa zonal wind averaged over $30^{\circ}-35^{\circ} \mathrm{N}$ and $130^{\circ}-160^{\circ} \mathrm{E}$.

Figure 3 shows indices for the ERA40 dataset (left blue box with the middle value for climatological mean and upper and lower value for one standard deviation), CMIP5 climatology (middle red box with the middle value for the MME, upper and lower values for the intra-model standard deviation, and uppermost and lowermost bars for maximum and minimum values) and CMIP3 climatology (right green box with the middle value for the MME, upper and lower values for the intra-model standard deviation, and uppermost and lowermost bars for maximum and minimum values). The MME SAT over East Asia shows large improvements in CMIP5 with both a temperature increase and intra-model standard deviation decrease. In addition, the maximum and minimum values of SAT in the CMIP5 models are closer to the MME than in the CMIP3 models. Model development and improvement is demonstrated by the fact that the intra-model standard deviations for most indices have decreased, especially for the east-west SLP contrast (Fig. 3c), SLP over eastern China (Fig. 3b), and the $200-\mathrm{hPa}$ jet stream (Fig. 3f), reflecting improved consistency between models. Improvements can also be observed in the climatology of the 200-hPa jet stream index (Fig. 3f), with slightly stronger westerlies predicted by the CMIP5 models than CMIP3 models. Because stronger westerlies help to suppress baroclinic wave activity (Nakamura 1992), this might suggest weak synoptic-scale wave activities and rapid movements of the short waves in the CMIP5 models.

The mean value differences are small for SLP over eastern China (Fig. 3b) between CMIP5 and CMIP3, indicating that consistency is maintained between generations of CGCMs in simulating large-scale circulations. The near surface northerly wind (Fig. 3d) is weaker than in observations and CMIP3 models, and the zonal SLP difference between the Siberian high and the Aleutian low (Fig. 3c) is weaker than in observations and the CMIP3 models. Meanwhile, the major trough along the EA coastal region is both stronger in the CMIP3 and CMIP5 models, with the CMIP5 models predicting much stronger trough intensity. This imperfection in the CMIP3 and CMIP5 models is associated with global-scale geopotential height biases, with most models showing a stronger polar vortex and lower geopotential heights in the mid and high latitudes.

\subsection{Radiation energy budget}

The CMIP5 model improvements in simulating the SAT are most likely related to the local radiation budget change. Figure 4 shows the MME difference of surface downward shortwave radiation (Fig. 4a), surface downward longwave radiation (Fig. 4b), surface upward shortwave radiation (Fig. 4c), surface upward longwave radiation (Fig. 4d), and the net radiation (the combination of the previous 4 components, Fig. 4e) between the CMIP5 and CMIP3 models. As for the net radiation (Fig. 4e), increased radiative energy fluxes are observed over East Asia, especially in southern and eastern China where the maximum fluxes along the central China Yangtze River basin are contained. This change can explain the increase in SAT predicted by the CMIP5 models over East Asia and characterise the northward shift of the $0{ }^{\circ} \mathrm{C}$ isotherm shown in Fig. 1a. The net radiation in Fig. 4e is composed of radiation components from Fig. 4a-d. Over the East Asia oceanic region, 
(a) CMIP5-CMIP3 rsds

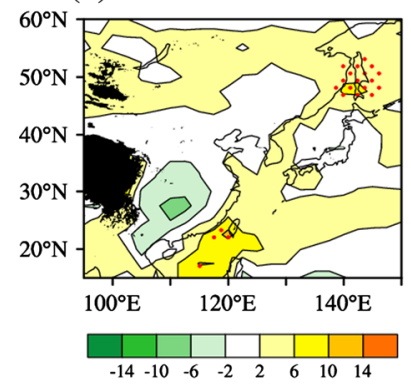

(c) CMIP5-CMIP3 rsus

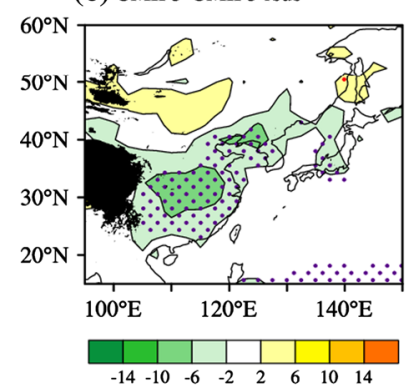

(e) CMIP5-CMIP3 net radiation

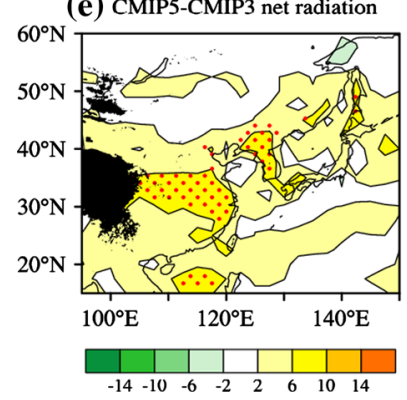

(b) CMIP5-CMIP3 rlds

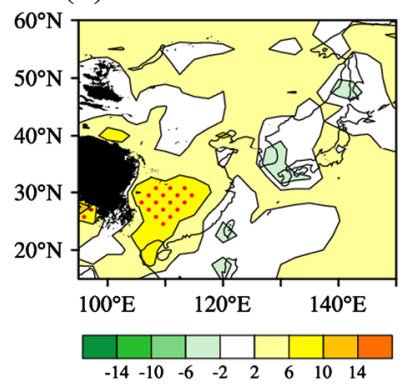

(d) CMIP5-CMIP3 rlus

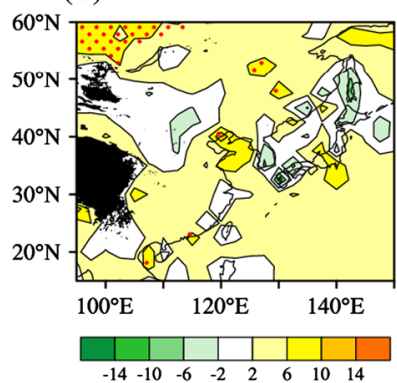

Fig. 4 The differences of the MME a surface downward shortwave radiation (rsds), b surface downward longwave radiation (rlds), c surface upward shortwave radiation (rsus), d surface upward longwave radiation (rlus), and $\mathbf{e}$ the net radiation (the combination of the previous 4 components) between the CMIP5 and CMIP3 models

the net radiation change is mainly dominated by downward shortwave radiation changes (Fig. 4a), which can be associated with the convective precipitation change (Fig. 2e) in this region, where less convective precipitation is related to less convective cumulus clouds and thus more downward shortwave radiation. The simulated convective precipitation decrease and the associated downward shortwave radiation increase are possible because of improvements to the convective parameterisations in the current CMIP5 models.

The net radiation over the mainland is mainly caused by less surface upward shortwave radiation (Fig. 4c) and more surface downward longwave radiation (Fig. 4b). Because the upward shortwave radiation is mainly influenced by surface albedo, the inclusion of time-evolving land cover changes in the CMIP5 historical simulation is thought to lead to the upward shortwave radiation decrease.

Accordingly, the use of constant land cover in previous CMIP3 simulations overestimate the surface albedo in East Asia. However, we can attribute the increased downward longwave radiation in CMIP5 to higher SAT and potentially an increased proportion of low-level stratus clouds in the CMIP5 simulations because both the atmospheric temperature and the amount of low-level stratus cloud can influence the downward longwave radiation.

Most CMIP5 models have updated their radiation scheme to accommodate the direct and/or indirect effects of aerosols. Several models have also updated cumulus parameterisation schemes. For example, the models that participated in CMIP3 from the National Center for Atmospheric Research (NCAR) were the NCAR_CCSM3.0 and NCAR_PCM1 models, which used the Community Atmosphere Model 3 (CAM3) as the atmospheric component. In CMIP5, NCAR used CAM4 in CCSM4, CESM1-BGC, CESM-FASTCHEM, and CESM1-WACCM, which updated the previous CAM3 deep convection scheme and resulted in an improved and less frequent occurrence of deep convection (Gent et al. 2011). NCAR also submitted the CESM-CAM5 model, which used CAM5 and took into account aerosol indirect effects and newly developed parameterisations for cloud fraction, cloud particle formation, convection and turbulence. Meanwhile, new moist turbulence and shallow convection parameterization schemes were adopted, which lead to substantial improvements in the simulation of shallow clouds in the boundary layer (Hurrell et al. 2013). These model improvements all help to provide a more reliable radiation energy budget and lead to a more realistic SAT distribution.

\section{The interannual variability}

The intensity of the interannual variability of the EAWM can be described by the standard deviation (STD) of the winter monsoon parameters. Figure 5 shows the STD of the surface temperature (shading) and the SLP (contour). The STD of surface temperature is largest at high latitudes. Substantial variability also occurred over eastern China, which is seen as a significant southward extension in this region. The CMIP3 and CMIP5 MME reproduced the large variability at high latitudes and the southward extension over eastern China. However, both the CMIP3 and CMIP5 simulations overestimate the southward extension of large surface temperature STD over eastern China, while underestimating the STD in the higher latitudes of EA, especially northward of $50^{\circ} \mathrm{N}$. On the interannual timescale, the East Asia winter climate is modulated by ENSO at the lower latitudes and by atmospheric internal processes at the higher latitudes (Chen et al. 2000; Huang et al. 2003; Jhun and Lee 2004). Therefore, an overestimation of SAT 
Fig. 5 The standard deviation (STD) of the surface air temperature (shading, units: ${ }^{\circ} \mathrm{C}$ ) and the sea level pressure (contours, units: hPa) for a observation, ERA40 reanalysis data (30-year climatology from 1971 to 2000), b CMIP5-MME, c CMIP3MME (2,071-2,100), d the differences between CMIP5MME and ERA40, and e the differences between CMIP3MME and $\mathbf{e}$ the differences between CMIP3-MME and ERA40. The contour intervals are $1 \mathrm{hPa}$ for $(\mathbf{a}-\mathbf{c})$ and $0.1 \mathrm{hPa}$ for (d). Dots signify statistically significant regions above the $5 \%$ level for surface air temperature according to Student's t test (a) Obs (ERA)

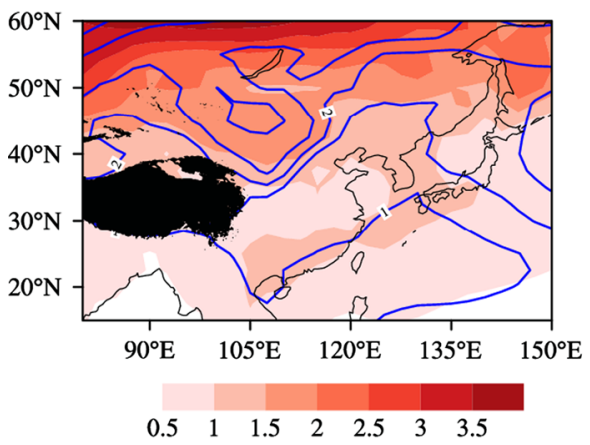

(c) MME (CMIP5)

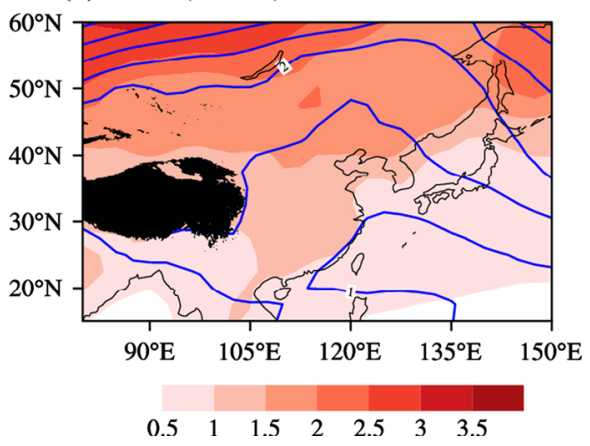

(b) MME (CMIP3)

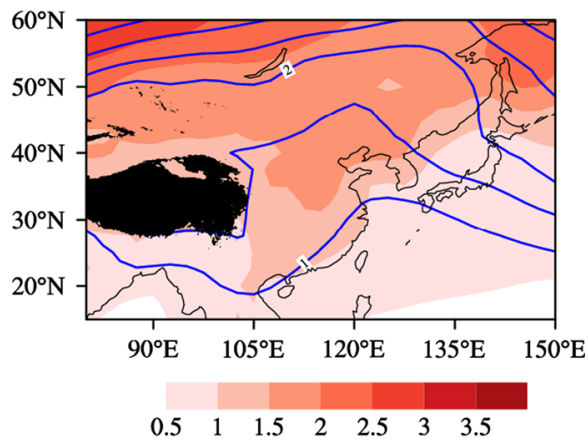

(d) MME (CMIP5-CMIP3)

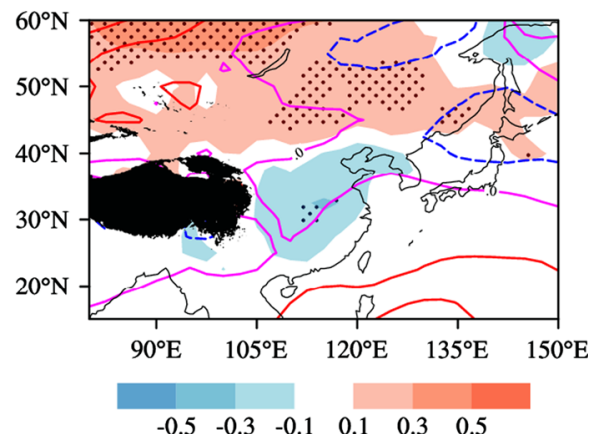

STD over eastern China may suggest excessive influences by ENSO, while the overestimation of the interannual variability may suggest insufficient modulation by the atmospheric internal processes at the higher latitudes.

The comparison of the CMIP5 and CMIP3 for SAT STD shows significant improvements in the CMIP5 models: (1) a negative SAT STD difference is evident between the CMIP5 and CMIP3 MME over southern and eastern China, indicating that the overestimation of interannual variability over this region is suppressed; and (2) a positive SAT STD difference is evident over the higher latitude northward of $40^{\circ} \mathrm{N}$, suggesting that the underestimation of the interannual variability at the higher latitudes is diminishing.

\section{The seasonal evolution of EAWM}

The seasonal evolution of the winter monsoon climate in East Asia can be divided into three phases, i.e., the setup phase in early winter, the mature phase in midwinter, and the withdrawal phase in late winter. During the setup phase, the zonal pressure gradient between the Siberian high and Aleutian low, and surface northerlies are formed. The mature phase of the EAWM has the lowest temperature and strongest surface northerlies over EA. However, the pressure gradient and surface northerlies decrease during the EAWM withdrawal. The main EAWM seasonal evolution features are shown in Fig. 6, namely, the monthly SLP difference between $110^{\circ} \mathrm{E}$ and $160^{\circ} \mathrm{E}$ (averaged from $20^{\circ} \mathrm{N}$ to $60^{\circ} \mathrm{N}$ ) and the northward nearsurface wind averaged over $15^{\circ}-30^{\circ} \mathrm{N}, 115^{\circ}-130^{\circ} \mathrm{E}$ for EAR40, CMIP5 and CMIP3 simulations. The seasonal cycle of the EAWM is most evident in the SLP differences: (1) negative values in August and May, indicating the summer monsoon period; (2) small values in September and April, indicating a transition between the winter monsoon and summer monsoon; (3) positive values throughout the winter months from October to March, which is directly associated with the setup of the Siberian high and Aleutian Low; and (4) the SLP differences reach their maximums in January, quasigeostrophically corresponding to northerlies along coastal East Asia. All of these features are evident in both the CMIP5 and CMIP3 simulations, indicating a perfect reproduction of the EAWM seasonal evolution. However, in both the CMIP5 and CMIP3 simulation, the SLP difference is systematically larger in the early winter months of October and November, while it is smaller in January, February and March. Therefore, current models tend to predict a rapid EAWM build-up in early winter, while have a weak SLP contrast between the Siberian High and Aleutian Low in mid and late winter. As the stationary planetary-scale asymmetric forcing between the land and ocean acts as the major forcing factors for the EAWM, the weak SLP contrast may suggest weak stationary forcing in the current models.

The annual cycle of temperature over the EA (averaged from $110^{\circ} \mathrm{E}$ to $120^{\circ} \mathrm{E}$ ) is displayed in Fig. 7. The decreasing temperatures in late autumn and early winter 
(a) SLP diff. $\left(110^{\circ}-160^{\circ} \mathrm{E}\right)$

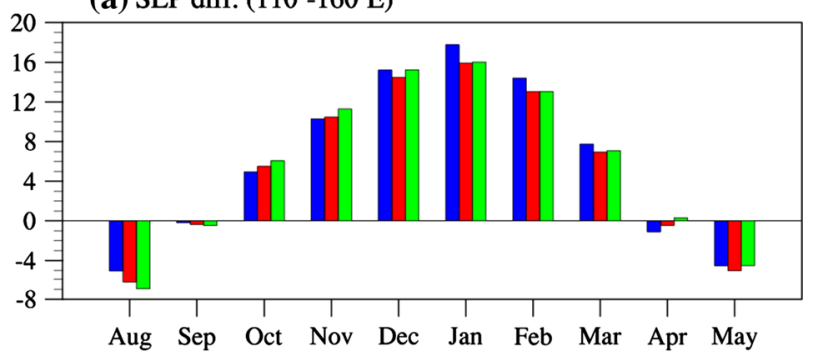

(b) VAS $\left(15^{\circ}-30^{\circ} \mathrm{N}, 115^{\circ}-130^{\circ} \mathrm{E}\right)$

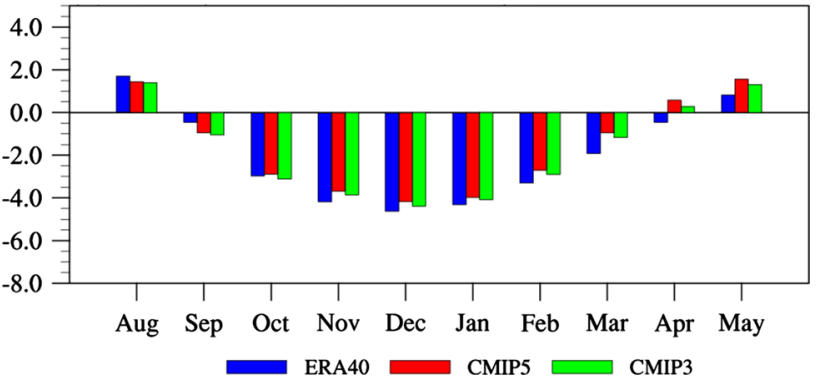

Fig. 6 a The monthly SLP difference between $110^{\circ} \mathrm{E}$ and $160^{\circ} \mathrm{E}$ averaged between $10^{\circ} \mathrm{N}$ and $60^{\circ} \mathrm{N}$ and $\mathbf{b}$ the monthly near-surface northward wind index along the East Asian coastal region (averaged for the region: $\left.15-30^{\circ} \mathrm{N}, 115-130^{\circ} \mathrm{E}\right)$. Blue ERA40, red CMIP5 and green CMIP3

followed by rising temperatures in late winter and spring are indicative of the winter season evolution. This seasonal variation is synchronous with the seasonal advance and retreat of the EAWM. Compared with the seasonal temperature evolution derived from ERA40 reanalysis, the CMIP3 and CMIP5 MME reasonably captured the cold period and its southward extension in historical simulations (Fig. $7 \mathrm{~b}, \mathrm{c}$ ). At $40^{\circ} \mathrm{N}$, the CMIP3 average temperature dropped below $0{ }^{\circ} \mathrm{C}$ in late October, decreasing to a minimum in January, and rising above $0^{\circ} \mathrm{C}$ in early March. The $0{ }^{\circ} \mathrm{C}$ line extended to $\sim 31^{\circ} \mathrm{N}$ in January. These features are consistent with the observed data, while the exact duration of winter was slightly lengthened and the $0{ }^{\circ} \mathrm{C}$ line extended approximately $3^{\circ}$ southward compared to the reanalysis.

Figure $7 d$ and e show that both the CMIP5 and CMIP3 simulations estimate lower temperatures over EA during the winter season, except for the lower latitudes $\left(20^{\circ}-\right.$ $30^{\circ} \mathrm{N}$ ) in February, March and April. In the CMIP3 MME, the maximum cold bias is about $-3{ }^{\circ} \mathrm{C}$ around $30^{\circ} \mathrm{N}$ in November and December, and about $-2{ }^{\circ} \mathrm{C}$ around $30^{\circ} \mathrm{N}$ in November and December in CMIP5 MME. Therefore, to a certain degree, the cold bias is suppressed in the CMIP5 MME. The difference between the CMIP5 and CMIP3 MME manifests itself as a warming in EA (Fig. 7f). The maximum warming is approximately $1{ }^{\circ} \mathrm{C}$ in late winter and above $0.5^{\circ} \mathrm{C}$ in other months southward of $40^{\circ} \mathrm{N}$. Therefore, the $0{ }^{\circ} \mathrm{C}$ margins withdrew to $\sim 33^{\circ} \mathrm{N}$ in

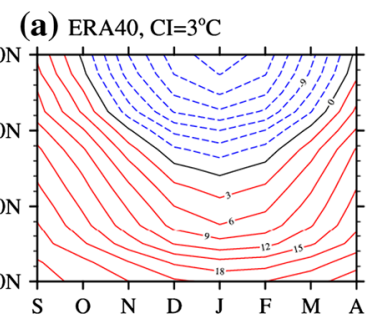

(c) $\mathrm{CMIP} 3, \mathrm{CI}=3^{\circ} \mathrm{C}$

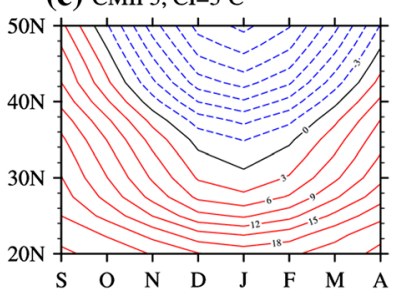

(e) CMIP3-ERA $40, \mathrm{CI}=0.5^{\circ} \mathrm{C}$

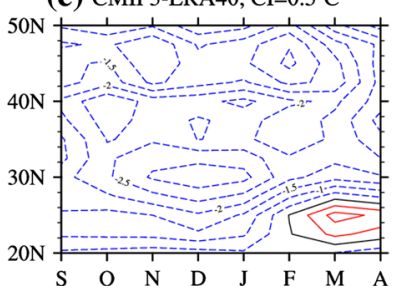

(b) $\mathrm{CMIP} 5, \mathrm{CI}=3^{\circ} \mathrm{C}$

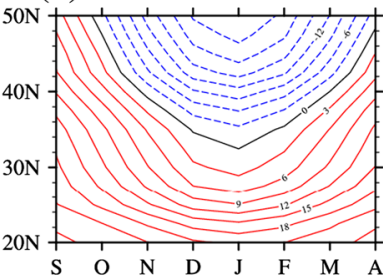

(d) CMIP5-ERA40, $\mathrm{CI}=0.5^{\circ} \mathrm{C}$

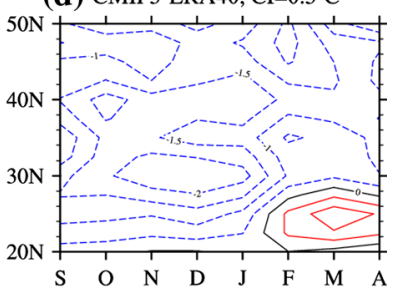

(f) $\mathrm{CMIP} 5-\mathrm{CMIP} 3, \mathrm{CI}=0.5^{\circ} \mathrm{C}$

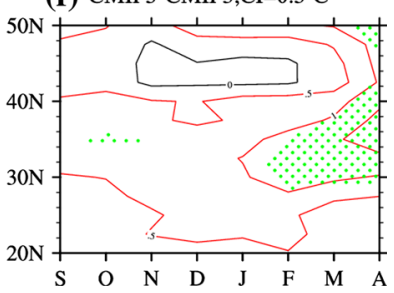

Fig. 7 Climatological annual cycle of $110^{\circ} \mathrm{E}-120^{\circ} \mathrm{E}$ zonal-mean temperature from a ERA40 reanalysis (averaged from 1971 to 2000), b CMIP5-historical (averaged from 1971 to 2000), c CMIP3, d the difference between CMIP5 and ERA40, e the differences between CMIP3 and ERA40, and $\mathbf{f}$ the differences between the CMIP5 and CMIP3 model simulations

January in the CMIP5 MME (Fig. 7b) and the wintertime is slightly shortened compared with the CMIP3 MME.

\section{Summaries and discussions}

We compared the climatology of the EAWM with two groups of CGCMs, i.e., the CMIP5 and CMIP3 model. These two phases of CMIP models, representing the best understanding of the climate system at that time, are widely used in the AR4 and AR5 of the IPCC, respectively. Studies have shown that the CMIP3 models have some common biases in the simulation of the EAWM climatology. For example, most models have negative temperature biases and positive precipitation biases over EA. These deficiencies of the CGCMs will limit and influence the accurate evaluation of climate change and climate projection over EA. Many improvements have been made in the current CMIP5 models. As for the EAWM, the biases have been greatly reduced, with an average SAT increase of 0.5 degrees over EA compared with the CMIP3 simulations. Accordingly, the SAT margin of $0{ }^{\circ} \mathrm{C}$ moves northward by approximately $1^{\circ}$, indicating a northward retreat of snow cover in the CMIP5 
model simulation. Meanwhile, the CMIP5 models predict a rainfall decrease over the EA region, especially over the coastal and oceanic region. Improvements can also be observed in the near surface wind speed; the region with strong winds along the coastal flank of EA in the CMIP5 simulation is closer to the reanalysis. It is important that the inter-model variance decreases in the above-mentioned EAWM parameters, especially in the averaged EA SAT, averaged EA SLP, and EA jet stream, signifying that the CMIP5 models show more consistency in the simulation of EAWM. The reduction of cold biases in CMIP5 models helps to better characterise the winter seasonal evolution over EA. In theCMIP3 MME, the winter was slightly lengthened and the $0{ }^{\circ} \mathrm{C}$ line extended farther southward than suggested by the observations. However, in the CMIP5 MME, winter was shortened and the $0{ }^{\circ} \mathrm{C}$ line withdrew approximately 2 degrees northward in January.

The decreasing cold biases in EA are probably associated with the radiative energy budget changes. The net radiative energy flux increases over East Asia, especially in southern and eastern China. Further analysis reveals that the net radiation change is mainly caused by less surface upward shortwave radiation and more surface downward longwave radiation. Because the land cover change is crucial to the value of surface albedo, it's an important improvement to replace the CMIP3 constant land cover with time-evolving land cover in the CMIP5 historical simulation. On the other hand, the SAT increase leads to northward withdraw of the SAT field in the CMIP5 simulations. As the $0{ }^{\circ} \mathrm{C}$ line can be used as the southern boundary of the snowfield, the northward withdraw of the winter snowfield can also lead to surface albedo decrease. Both can help to result in the decrease of the upward shortwave radiation. Because the surface downward longwave radiation is mainly determined by both the atmospheric temperature and the amount of low-level stratus cloud, the increased downward longwave radiation in the CMIP5 simulation is attributed to higher SAT and potentially an increased proportion of low-level stratus clouds over East Asia in the CMIP5 models.

Both the CMIP3 and CMIP5 overestimate the precipitation over the East Asia oceanic region. In CMIP5, the overestimation is decreased, which can be mainly attributed to the decrease in convective precipitation. As stratiform rainfall reigns over East Asia, with a percentage of approximately $50-85 \%$ in winter (Du et al. 2011), the overestimation of precipitation by the CMIP3 and CMIP5 is most likely due to the overestimation of convective clouds in East Asia. The decrease of convective rainfall in the CMIP5 models produce an increased proportion of stratiform clouds over East Asia, possibly due to improvement of the convection scheme. However, more advancements are still needed.
Both the CMIP3 and CMIP5 models can characterise the main features of the SAT variability on interannual timescale, with larger SAT standard deviations at high latitudes and a significant southward extension east of Tibetan Plateau. The CMIP3 and CMIP5 models have some common bias, i.e., overestimation of the southward extension of large SAT STD over eastern China and underestimation of the SAT STD values at EA higher latitudes. However, the overestimation of the SAT STD over eastern China and the underestimation of SAT STD at EA higher latitudes are both suppressed in the CMIP5 simulation. Because the EAWM is modulated by various external and internal factors, the improvement in the simulation of the SAT STD might suggest an improvement in the predictability on interannual timescales.

Although the CMIP5 models perform well in reproducing the EAWM climatology, there are still some deficiencies. For example, the near surface northerlies are weaker than suggested by observations and the CMIP3 models. The zonal SLP difference between the Siberian high and Aleutian low is weaker than in observations and the CMIP3 models. The 500-hPa major trough strength is too strong in EA. Lastly, the cold bias still exists in the current CMIP5 models. Therefore, additional model improvements are still required to better simulate the EAWM.

Acknowledgments This research is supported by the National Basic Research Program of China (973 Program) (Grant No. 2010CB 428603), and the National Natural Science Foundation of China (Grant No. 41175041).

\section{References}

Bao Q, Yang J, Liu Y, Wu G, Wang B (2010) Roles of anomalous Tibetan Plateau Warming on the severe 2008 winter storm in central-southern China. Mon Weather Rev 138:2375-2384. doi:10.1175/2009mwr2950.1

Bao Q, Lin P, Zhou T, Liu Y, Yu Y, Wu G, He B, He J, Li L, Li J, Li Y, Liu H, Qiao F, Song Z, Wang B, Wang J, Wang P, Wang X, Wang Z, Wu B, Wu T, Xu Y, Yu H, Zhao W, Zheng W, Linjiong $Z$ (2013) The flexible global ocean-atmosphere-land system model, spectral version 2: FGOALS-s2. Adv Atmos Sci 30:561-576

Boo K-O, Martin G, Sellar A, Senior C, Byun Y-H (2011) Evaluating the East Asian monsoon simulation in climate models. J Geophys Res 116. doi:10.1029/2010jd014737

Bueh C (2003) Simulation of the future change of East Asian monsoon climate using the IPCC SRES A2 and B2 scenarios. Chin Sci Bull 48:1024-1030. doi:10.1360/02wd0368

Bueh C, Ji L (1999) Anomalous activity of East Asian winter monsoon and the tropical Pacific SSTA. Chin Sci Bull 44:890-898

Chan JCL, Li C (2004) The East Asia winter monsoon. In: Chang C-P (ed) East Asian monsoon. World Scientific Publishing Company, Singapore, pp 54-106

Chang CP, Erickson JE, Lau KM (1979) Northeasterly cold surges and near-equatorial disturbances over the winter MONEX area 
during December 1974. Part I: Synoptic aspects. Mon Weather Rev 107:812-829

Chang C-P, Lu M-M, Wang B (2011) The East Asian winter monsoon: research and forecast. In: Chang C-P, Ding Y, Lau $\mathrm{N}-\mathrm{C}$, Johnson RH, Wang B, Yasunari T (eds) The global monsoon system. World Scientific, Singapore, pp 99-110

Chen J, Sun SQ (1999) East Asian winter monsoon anomaly and variation of global circulation. Part I: a comparison study on strong and weak winter monsoon. Chin J Atmos Sci 23:101-111

Chen W, Graf HF, Huang R (2000) The interannual variability of East Asian winter monsoon and its relation to the summer monsoon. Adv Atmos Sci 17:46-60

Chen MY, Xie PP, Janowiak JE, Arkin PA (2002) Global land precipitation: a 50-year monthly analysis based on gauge observations. J Hydrometeorol 3:249-266. doi:10.1175/15257541(2002)003<0249: glpaym>2.0.co;2

Chen GTJ, Wang CC, Lin DTW (2005a) Characteristics of low-level jets over northern Taiwan in Mei-Yu season and their relationship to heavy rain events. Mon Weather Rev 133:20-43. doi:10. 1175/mwr-2813.1

Chen W, Yang S, Huang RH (2005b) Relationship between stationary planetary wave activity and the East Asian winter monsoon. J Geophys Res 110:D14110. doi:14110.11029/12004JD005669

Cui X, Sun Z (1999) East Asian winter monsoon index and its variation analysis. J Nanjing Inst Meteorol 22:321-325

Du Z, Huang R, Huang G, Chen J (2011) The characteristics of spatial and temporal distributions of convective rainfall and stratiform rainfall in the Asian monsoon region and their possible mechanisms. Chin J Atmos Sci 35:993-1008

Gent PR, Danabasoglu G, Donner LJ, Holland MM, Hunke EC, Jayne SR, Lawrence DM, Neale RB, Rasch PJ, Vertenstein M (2011) The community climate system model version 4. J Clim 24:4973-4991

Gong DY, Wang SW, Zhu JH (2001) East Asian winter monsoon and Arctic oscillation. Geophys Res Lett 28:2073-2076

Gu L, Wei K, Huang R (2008) Severe disaster of blizzard, freezing rain and low temperature in January 2008 in China and Its Association with the anomalies of East Asian monsoon system. Clim Environ Res 13:405-418

Guo Q (1994) Relationship between the variations of East Asian winter monsoon and temperature anmalies in China. Q J Appl Meteorol 5:218-225

He S, Wang H (2012) Analysis of the decadal and interdecadal variations of the East Asian winter monsoon as simulated by 20 coupled models in IPCC AR4. Acta Meteorol Sin 26:476-488. doi:10.1007/s13351-012-0407-6

Hori ME, Ueda H (2006) Impact of global warming on the East Asian winter monsoon as revealed by nine coupled atmosphere-ocean GCMs. Geophys Res Lett 33. doi:L0371310.1029/2005g1024961

Hu ZZ, Bengtsson L, Arpe K (2000) Impact of global warming on the Asian winter monsoon in a coupled GCM. J Geophys Res 105:4607-4624. doi:10.1029/1999jd901031

Huang RH, Zhou LT, Chen W (2003) The progresses of recent studies on the variabilities of the East Asian monsoon and their causes. Adv Atmos Sci 20:55-69

Huang R, Chen W, Yan B, Zhang R (2004) Recent advances in studies of the interaction between the East Asian winter and summer monsoons and ENSO cycle. Adv Atmos Sci 21: 407-424

Hurrell JW, Holland MM, Gent PR, Ghan S, Kay JE, Kushner PJ, Lamarque JF, Large WG, Lawrence D, Lindsay K, Lipscomb WH, Long MC, Mahowald N, Marsh DR, Neale RB, Rasch P, Vavrus S, Vertenstein M, Bader D, Collins WD, Hack JJ, Kiehl J, Marshall S (2013) The community earth system model: a framework for collaborative research. Bull Am Meteorol Soc. doi:10.1175/BAMS-D-12-00121
Jhun JG, Lee EJ (2004) A new East Asian winter monsoon index and associated characteristics of the winter monsoon. J Clim 17:711-726

Jiang DB, Wang HJ, Lang XM (2005) Evaluation of East Asian climatology as simulated by seven coupled models. Adv Atmos Sci 22:479-495

Jiang Y, Luo Y, Zhao Z (2010) Projection of wind speed changes in China in the 21st century by climate models. Chin J Atmos Sci 34:323-336

Kang IS, Jin K, Wang B, Lau KM, Shukla J, Krishnamurthy V, Schubert SD, Wailser DE, Stern WF, Kitoh A, Meehl GA, Kanamitsu M, Galin VY, Satyan V, Park CK, Liu Y (2002) Intercomparison of the climatological variations of Asian summer monsoon precipitation simulated by 10 GCMs. Clim Dyn 19:383-395. doi:10.1007/s00382-002-0245-9

Kim H-J, Wang B, Ding Q (2008) The global monsoon variability simulated by CMIP3 coupled climate models. J Clim 21:5271-5294. doi:10.1175/2008jcli2041.1

Kimoto M (2005) Simulated change of the East Asian circulation under global warming scenario. Geophys Res Lett 32:L16701. doi:10.1029/2005gl023383

Kusunoki S, Arakawa O (2012) Change in the precipitation intensity of the East Asian summer monsoon projected by CMIP3 models. Clim Dyn 38:2055-2072. doi:10.1007/s00382-011-1234-7

Lau KM, Chang CP (1987) Planetary scale aspects of the winter monsoon and atmospheric teleconnections. In: Chang $\mathrm{CP}$, Krishnamurti TN (eds) Monsoon meteorology. Oxford University Press, New York, pp 161-202

Lau KM, Peng L (1987) Origin of low-frequency (intraseasonal) oscillations in the tropical atmosphere. Part I: basic theory. J Atmos Sci 44:950-972

Li C (1990) Interaction between anomalous winter monsoon in East Asia and El Nino events. Adv Atmos Sci 7:36-46

Li Y, Lu R, Dong B (2007) The ENSO-Asian monsoon interaction in a coupled ocean-atmosphere GCM. J Clim 20:5164-5177

Meehl GA, Covey C, McAvaney B, Latif M, Stouffer RJ (2005) Overview of the coupled model intercomparison project. Bull Am Meteorol Soc 86:89-93. doi:10.1175/bams-86-1-89

Min SK, Park EH, Kwon WT (2004) Future projections of East Asian climate change from multi-AOGCM ensembles of IPCCSRES scenario simulations. J Meteorol Soc Japan 82:1187-1211. doi: $10.2151 / \mathrm{jmsj} .2004 .1187$

Nakamura H (1992) Midwinter suppression of baroclinic wave activity in the Pacific. J Atmos Sci 49:1629-1642

Paul S, Hsu H-H (2012) Comparative study of performance of CMIP3 GCMs in simulating the East Asian monsoon variability. Terr Atmos Ocean Sci 23:377-395. doi:10.3319/tao.2012.02.01. 01(a

Randall DA, Wood RA, Bony S, Colman R, Fichefet T, Fyfe J, Kattsov V, Pitman A, Shukla J, Srinivasan J, Stouffer RJ, Sumi A, Taylor KE (2007) Cilmate models and their evaluation. In: Solomon S, Coauthors (eds) The physical science basis contribution of working group i to the fourth assessment report of the Intergovernmental Panel on Climate Change. Cambridge University Press, Cambridge and New York, pp 591-662

Song F, Zhou T (2013) FGOALS-s2 simulation of upper-level jet streams over East Asia: mean state bias and synoptic-scale transient eddy activity. Adv Atmos Sci 30:739-753

Sun B, Sun S (1994) The analysis on the features of the atmospheric circulation in preceding winters for the summer drought and flooding in the Yangtze and Huaihe River Valley. Adv Atmos Sci 11:79-90

Tao SY, Wei J (2008) Severe snow and freezing-rain in January 2008 in the Southern China. Clim Environ Res 13:337-350

Taylor KE, Stouffer RJ, Meehl GA (2012) An overview of CMIP5 and the experiment design. Bull Am Meteorol Soc 93:485 
Tian Z, Jiang D, Zhang R, Sui Y (2012) Long-term climate simulation of CCSM4.0 and evaluation of Its performance over East Asia and China. Chin J Atmos Sci 36:619-632

Uppala SM, KÅllberg PW, Simmons AJ, Andrae U, Da Costa Bechtold V, Fiorino M, Gibson JK, Haseler J, Hernandez A, Kelly GA, Li X, Onogi K, Saarinen S, Sokka N, Allan RP, Andersson E, Arpe K, Balmaseda MA, Beljaars ACM, Van De Berg L, Bidlot J, Bormann N, Caires S, Chevallier F, Dethof A, Dragosavac M, Fuentes M, Hagemann S, Holm E, Hoskins BJ, Isaksen L, Janssen PAEM, Jenne R, McNally AP, Mahfouf JF, Morcrette JJ, Rayner NA, Saunders RW, Simon P, Sterl A, Trenberth KE, Untch A, Vasiljevic D, Viterbo P, Woollen J (2005) The ERA-40 re-analysis. Q J R Meteorol Soc 131:2961-3012

Wang L, Chen W, Zhou W, Huang R (2009) Interannual variations of East Asian trough axis at $500 \mathrm{hPa}$ and its association with the East Asian winter monsoon pathway. J Clim 22:600-614

Wang B, Wu Z, Chang C-P, Liu J, Li J, Zhou T (2010) Another look at interannual-to-interdecadal variations of the East Asian winter monsoon: the northern and southern temperature modes. J Clim 23:1495-1512. doi:10.1175/2009jcli3243.1

Watanabe M (2004) Asian jet waveguide and a downstream extension of the North Atlantic oscillation. J Clim 17:4674-4691

Watanabe M, Nitta T (1999) Decadal changes in the atmospheric circulation and associated surface climate variations in the Northern Hemisphere winter. J Clim 12:494-510. doi:10.1175/ 1520-0442(1999)012<0494:dcitac >2.0.co;2

Wei K, Bao Q (2012) Projections of the East Asian winter monsoon under the IPCC AR5 scenarios using a coupled model: IAPFGOALS. Adv Atmos Sci 29:1200-1214. doi:10.1007/s00376012-1226-5

Wei K, Chen W, Zhou W (2011) Changes in the East Asian cold season since 2000. Adv Atmos Sci 28:69-79
Wu B, Wang J (2002) Winter arctic oscillation, siberian high and East Asian winter monsoon. Geophys Res Lett 29:1897. doi:0.1029/ 2002GL015373

Wu G, Zhang Y (1998) Tibetan plateau forcing and the timing of the monsoon onset over South Asia and the South China Sea. Mon Weather Rev 126:913-927

Wu RG, Hu ZZ, Kirtman BP (2003) Evolution of ENSO-related rainfall anomalies in East Asia. J Clim 16:3742-3758

Yan HM, Yang H, Yuan Y, Li CY (2011) Relationship between East Asian winter monsoon and summer monsoon. Adv Atmos Sci 28:1345-1356. doi:10.1007/s00376-011-0014-y

Yang S, Lau KM, Kim KM (2002) Variations of the East Asian jet stream and Asian-Pacific-American winter climate anomalies. J Clim 15:306-325

Ye DZ, Gao YX (1979) Tibetan plateau meteorology. Science Press, Beijing, $279 \mathrm{pp}$

Zhang H, Chen H (2011) Evaluation of summer circulation simulation over East Asia by 21 climate models II:interannual variability. Sci Meteorol Sin 31:247-257

Zhang CJ, Zhang HQ (2010) Potential impacts of East Asian winter monsoon on climate variability and predictability in the Australian summer monsoon region. Theor Appl Climatol 101:161-177. doi:10.1007/s00704-009-0246-2

Zhang R, Sumi A, Kimoto M (1996) Impact of El Nino on the East Asian monsoon: a diagnostic study of the'86/87 and'91/92 events. J Meteorol Soc Japan 74:49-62

Zhou W, Chan JCL, Chen W, Ling J, Pinto JG, Shao YP (2009) Synoptic-scale controls of persistent low temperature and icy weather over Southern China in January 2008. Mon Weather Rev 137:3978-3991. doi:10.1175/2009mwr2952.1 